\title{
"Whose Wife Will She Be at the Resurrection?" Marriage and Remarriage in Early Modern Russia
}

\author{
Daniel H. Kaiser
}

Now then, at the resurrection, whose wife will she be of the seven, since all of them were married to her?

-Matthew 22:28

For some time, but especially in recent years, historians have debated the extent to which the Russian Orthodox Church in the seventeenth century was able to affect personal behavior. In attempting to debunk the claim that Old Believers helped lead a mass movement of religious dissent, Georg Michels has remarked on the "apparent indifference demonstrated by the average Muscovite toward official ecclesiastical matters." Reports of low church attendance and of parishioners' failure to take communion, go to confession, observe fasts, or have children baptized all seemed to support the claim that at the parish level Orthodoxy exerted but weak authority in the seventeenth century, helping to explain, Michels argues, the efforts made by church officials late in the century to monitor priests' performance more closely. ${ }^{1}$

In fact, despite the evidence of misbehavior among parishioners, there are reasons to think that many Muscovite Christians, within the limits of their understanding, appropriated fundamental elements of Christian practice. ${ }^{2}$ For example, in spite of frequent protestations to the contrary, the only firm data we have on age at marriage indicate that only a tiny proportion of weddings in early modern Russia took place between underage brides and grooms. Most men and women of this era only married in their late teens or early twenties. ${ }^{3}$ Likewise, Muscovite-era dowry contracts indicate that early modern Russians rarely married on a Wednesday or Friday or during the various great fasts, when churchmen prohibited weddings. ${ }^{4}$ Furthermore, such evidence as we can muster on the timing of births seems to confirm that, just as church law prescribed, Muscovite Christians avoided sexual relations during Lent. ${ }^{5}$ And despite what

1. Georg Michels, At War with the Church: Religious Dissent in Seventeenth-Century Russia (Stanford, 1999), 188-89.

2. P. S. Stefanovich, Prikhod i prikhodskoe dukhovenstvo v Rossii v XVI-XVII vekakh (Moscow, 2002), 282.

3. D. Kaizer (Kaiser), "Vozrast pri brake i raznitsa v vozraste suprugov v gorodakh Rossii v nachale XVIII v.," in Sosloviia i gosudarstvennaia vlast' v Rossii XV-seredina XIX vr., 2 vols. (Moscow, 1994), 2:227-32.

4. Daniel H. Kaiser, "The Seasonality of Family Life in Early Modern Russia," Forschungen zur osteuropäischen Geschichte 46 (1992): 30-39; Kaiser, "Quotidian Orthodoxy: Domestic Life in Early Modern Russia," in Valerie A. Kivelson and Robert H. Greene, eds., Orthodox Russia: Belief and Practice under the Tsars and Beyond (University Park, 2003), $179-92$.

5. Kaiser, "Seasonality," 22-30.

Slavic Review 62, no. 2 (Summer 2003) 
observers might have said about the neglect of the baptismal font, few were the Muscovites in the seventeenth century who did not answer to a baptismal name. ${ }^{6}$

The sometimes sensational accounts of heterodoxy and sacrilege, together with the solemn asseverations of bishops in council, have encouraged historians to see the early modern Russian church as incapable of governing domestic life. For example, in writing about church efforts to regulate marital behavior in imperial Russia, Gregory Freeze observed that in the late eighteenth century churchmen "developed an entirely new capability for controlling matrimony and divorce" as well as "an increasingly restrictive policy on marital dissolution, one that virtually eliminated legal possibilities of terminating a marriage through annulment, divorce, or separation." 7 Freeze reports that clerics became so committed to the indissolubility of marriage that they refused to recognize remarriages, even when bigamous unions had resulted in children; wayward spouses were routinely returned to the partners whom they had abandoned. $^{8}$

In making this claim, Freeze contrasted the practice with "early modern Russia, where neither the state nor the church exercised much control." 9 Despite the nominal authority that medieval and early modern Russian clerics wielded over marriage, Freeze continued, churchmen could not exercise that power because of "institutional backwardness: the church simply lacked the instruments - unambiguous law, parish documentation, bureaucratic infrastructure - that would have enabled it to translate its formal authority into real power." In this view, therefore, Muscovite-era churchmen acted capriciously, and society quite understandably conceived of marriage as more secular than sacramental. ${ }^{10}$

There can be no doubt that eighteenth-century church courts acted vigorously to investigate and defend the inviolability of primary marriages, returning bigamists to their original spouses and imposing stiff punishments for violations of canon law. ${ }^{11}$ But this practice was hardly an innovation in the eighteenth century, as Freeze suggests. Quite the contrary, as records from the Russian north confirm: as early as the seventeenth century archepiscopal courts aggressively sought out those

6. Daniel H. Kaiser, "Naming Cultures in Early Modern Russia," Harvard Ukrainian Studies 19 (1995): 271-95.

7. Gregory L. Freeze, "Bringing Order to the Russian Family: Marriage and Divorce in Imperial Russia, 1760-1860," Journal of Modern History 62 (1990): 711.

8. Ibid., 725.

9. Ibid., 711 .

10. Ibid., 712-13. Freeze makes the same point in "The Wages of Sin: The Decline of Public Penance in Imperial Russia," in Stephen K. Batalden, ed., Seeking God: The Recovery of Religious Identity in Orthodox Russia, Ukraine, and Georgia (DeKalb, 1993), 55.

11. See, for example, N. P. Rozanov, "Semeinye bezobraziia bylago vremeni," Russkii arkhiv, 1894, bk. 3:319-21, 327-28. Nina Minenko reports that in eighteenth- and nineteenth-century western Siberia "peasants did not regard marriage as a permanent union'" and that peasant flight and remarriage were common. As the records she cites confirm, however, churchmen regularly investigated complaints about bigamy and attempted to restore partners to their original marriages. N. A. Minenko, Russkaia krest'ianskaia sem'ia v zapadnoi Sibiri: XVII-pervoi poloviny XIXv. (Novosibirsk, 1979), 210-13. 
who had abandoned spouses in order to take new partners and routinely returned runaways to their original mates. ${ }^{12}$ In attacking bigamous unions, seventeenth-century clerics, like their eighteenth-century successors, affirmed the sacramental primacy and indissolubility of first marriages. Likewise, by monitoring and discouraging remarriage, even for widows and widowers, churchmen made clear that, even if circumstances sometimes mandated allowing remarriage, first marriages had sacramental status that made them superior to all subsequent couplings. In enforcing this preference, seventeenth-century church courts showed themselves fully competent to ascertain the facts surrounding marital disputes and then to impose their decisions upon the principals. Lay people, for their part, even when they attempted to evade the sanctions of church courts, demonstrated that they, too, understood the Orthodox preference for first marriages, in this way confirming the success that attended Orthodox teaching about marriage in seventeenth-century Russia.

From the earliest days of Christianity in Rus', clerics struggled with native marriage practices and attempted to impose their preference for Christian weddings as the only means of legitimating sexual unions. Like western canonists, Orthodox officials saw in marriage a sacrament as well as a social institution. Because of the ways in which Christian scriptures employed marriage as a figure for salvation, Orthodox hierarchs were inclined to see the first marriage, ritualized and recognized by the church, as the only legitimate marriage, and the bond that it established as unbreakable. Not only was divorce, therefore, unwelcome, but any remarriage - even for widows and widowers - was little better than a concession to the flesh, a regrettable necessity. ${ }^{13}$ As early as the eleventh century Metropolitan Ioann had observed that a good Christian ought to marry no more than twice, no matter what the circumstances. ${ }^{14}$ But clerics' preference quite clearly was for just one marriage; invoking analogies from Eden and New Testament metaphors about Christ as bridegroom, Orthodox canonists insisted that "if God had commanded the taking of two or three wives, he would have created three wives for Adam; therefore multiple marriages are prohibited to Christians." ${ }^{15}$

Orthodox canonists sometimes conceded the possibility of remarriage, especially for widows and widowers, but they did so reluctantly and

12. I know of no complete inventory of such records, but it is clear that similar materials exist for Moscow and other central Russian eparchies. See T. N. Protas'eva, "Stolbtsy Sinodal'nogo sobraniia," Arkheograficheskii ezhegodnik za 1959 god (Moscow, 1960), 297.

13. Eve Levin, Sex and Society in the World of the Orthodox Slavs, 900-1700 (Ithaca, 1989), 105. On the conflicted history of western canonists' views on remarriage, see James A. Brundage, "Widows and Remarriage: Moral Conflicts and Their Resolution in Classical Canon Law," in Sue Sheridan Walker, ed., Wife and Widow in Medieval England (Ann Arbor, 1993), 17-31.

14. Russkaia istoricheskaia biblioteka (hereafter RIB), 39 vols. (St. Petersburg-Leningrad, 1872-1927), $6: 4.6$.

15. N. L. Pushkareva, ed., "A se grekhi zlye smertnye - ": Liubov', erotika i seksual'naia etika $v$ doindustrial'noi Rossii. X-pervaia polovina XIX v.: Teksty, issledovaniia (Moscow, 1999), 54; S. I. Smirnov, Materialy po istorii drevnerusskoi pokaiannoi distsipliny (Moscow, 1913), 64; Levin, Sex and Society, 106. See also Matt. 19:3-6. 
obliged those who remarried to perform various acts of penance. ${ }^{16}$ Third marriages provoked even more suspicions, but these, too, sometimes happened, although churchmen who performed weddings for the thricemarried were regarded with suspicion and could be removed from office as a result. ${ }^{17}$ According to Metropolitan Fotii, writing early in the fifteenth century, a third marriage was possible only when there were no children from the first two marriages, and even then canon law required penance. ${ }^{18}$

Fourth marriages, it seems, were absolutely forbidden. Although the text of Metropolitan Fotii's letter that discusses this subject diverges between the Novgorod copy, according to which a fourth marriage was inadmissible, and the Pskov copy, which imposed no more than stiff penance for a fourth marriage, the Pskov version has appended to it a long discourse in which Fotii clearly rules out a fourth marriage. The offender guilty of such an infraction could expect to be expelled from the church..$^{19} \mathrm{~A}$ late fifteenth-century instruction to churchmen absolutely prohibited a fourth marriage and decreed that anyone who persisted in this intention should be barred from church. ${ }^{20}$ Patriarch Adrian, too, cautioned priests against celebrating the fourth marriage of any man or woman. In addition, to give substance to the church's displeasure with remarriage, he stipulated that those who married for a second or third time were to pay correspondingly higher fees for marriage certificates (venechnye pamiati), which confirmed that the man and woman violated no church law in marrying one another. ${ }^{21}$

Of course, churchmen had always condemned bigamy and viewed the first marriage as having preempted the validity of the second. For example, the Statute of Grand Prince Iaroslav, which allegedly came from the court of the eleventh-century prince, Iaroslav the Wise, but which sur-

16. RIB 6:867-68.59.

17. Ibid., $6: 9.17,859.13$.

18. Ibid., 6:273, 282; Akty, sobrannye v bibliotekakh $i$ arkhivakh Rossiiskoi imperii Arkheograficheskoiu ekspeditsieiu Imperatorskoi Akademii nauk, 4 vols. (St. Petersburg, 1836), 1, no. 369; Russkii feodal'nyi arkhiv, 5 vols. (Moscow, 1986-92), 3, no. 141 and 2, no. 126.

19. RIB $6: 273,279-81$.

20. Akty istoricheskie, sobrannye $i$ izdannye Arkheograficheskoiu komissieiu, 5 vols. (St. Petersburg, 1841-43), 1, no. 109. Exactly that fate befell a late seventeenth-century priest who petitioned the archbishop about having presided over the wedding of a peasant whose bride became his fourth wife. According to the priest, parishioners had taken from him the keys to the church and had refused him entry because of his error. Ivan Nikolaevich Suvorov, Opisanie sobraniia svitkov nakhodiashchikhsia $v$ Vologodskom eparkhial' nom drevnekhranilishche, 13 pts. (Vologda, 1899-1917), 5:25. See also ibid., 1:27, 12:18-19.

21. Polnoe sobranie zakonov Rossiiskoi imperii (hereafter PSZ), 45 vols. (St. Petersburg, $1830), 3$, no. 1612, arts. 64,46 . Although churchmen long sought to collect wedding fees (venechnye poshliny), exactly when the document authorizing a wedding (venechnaia pamiat') came into practice is uncertain. S. I. Sirotkin reported that the earliest reference dated to 1488, but few survive from anytime before the seventeenth century. "Neskol'ko novykh dokumentov po istorii brachnogo prava na Rusi za XVII-XVIII w.," Chteniia v Imperatorskom obshchestve istorii i drevnostei rossiiskikh pri moskovskom universitete, 1896, no. 4, 41 . A 1630 wedding memorandum appears in Akty iuridicheskie ili sobranie form starinnogo deloproizvodstva (St. Petersburg, 1838), no. 403, and is reprinted in RIB 35, no. 375. Many more survive from late in the seventeenth century. See, for example, Pamiatniki pis'mennosti $v$ muzeiakh Vologodskoi oblasti. Katalog-putevoditel', pt. 4, no. 2 (Vologda, 1984), 107-13. 
vives only in copies no older than the fifteenth century, provided that if a man took a second spouse before the first had died, ecclesiastics were obliged to separate them and return the man to his original spouse. The new wife was to be imprisoned in a convent and was to pay fines to the metropolitan. Similarly, if a woman fled from her husband and married someone else, then, just like an adulterer, she was subject to incarceration in a convent and the payment of a fine. ${ }^{22}$

As the network of church authority did not stretch evenly and directly to all corners of the Muscovite realm, men and women seemed able to flee unhappy unions and quickly lose themselves in the forested stretches of Muscovy, far from their home parishes. When the possibility of remarriage arose, more than a few fugitives seized the moment and fashioned new partnerships, even though their original spouses might still have been alive somewhere else. ${ }^{23}$ The church, however, could not countenance such casual regard for matrimony; if marriage constructed an eternal bond, then certainly while both partners were still alive that bond remained intact. A sixteenth-century text censured wives who, when abandoned, took in replacement partners before learning the fate of their fugitive husbands. ${ }^{24}$ Similarly, a late seventeenth-century instruction cautioned clergy who composed the certificates authorizing marriage to make certain that the prospective bride and groom did not violate any of the church's prohibitions. The text is careful to specify that churchmen were to marry no man whose wife was still alive and no woman whose husband was still alive. ${ }^{25}$

But bigamy was not the churchmen's only concern. The same view of marriage affected clerical attitudes toward serial monogamy. ${ }^{26}$ Seeing in marriage a sacrament that connected man and woman in a spiritual as well as a physical relationship, churchmen found it difficult to encourage remarriage even for those whose spouses could be confirmed dead. The clergy who gathered in council in 1550-51 addressed this phenomenon

22. Ia. N. Shchapov, ed., Drevnerusskie kniazheskie ustavy $X I-X V$ vv. (Moscow, 1976), 87.9-10, 92.6-7, 95.10-11, 100.10-11, 104.10-11. The Short, Rumiantsev, and Tarnovsk redactions do not include the article that imagines a woman committing bigamy. Ibid., $111.9,117.9,122.9,129.9,133.9$.

23. In fairness to early modern Russians, their twentieth-century descendants could be every bit as ambitious in multiplying marital alliances. During the 1936 public discussion of the proposed new Soviet constitution, Maria Stepanovna Khudiakova of Cheliabinsk wrote to the newspaper Krest'ianskaia gazeta to complain about her own husband's misbehavior. She wrote that her husband had been "married to two other women besides me and they had one child apiece, I found out too late-I was already pregnant, and now he has gotten himself a fourth one and taken off." Lewis Siegelbaum and Andrei Sokolov, Stalinism as a Way of Life: A Narrative in Documents (New Haven, 2000), 198-99.

24. Pushkareva, ed., "A se grekhi zlye smertnye-," 97; Smirnov, Materialy, 47. The text did not articulate a similar provision for a man who acted equally precipitously.

25. PSZ 3, no. 1612, art. 63.

26. Pushkareva, ed., "A se grekhi zlye smertnye-," 97; Smirnov, Materialy, 48, 49. Orthodox priests, whom canon law and tradition required to be married, encountered special difficulties after the death of a spouse. See Debra Coulter, "The Muscovite Widowed Clergy and the Russian Church Reforms of 1666-1667," Slavonic and East European Review 80, no. 3 (July 2002): 459-78. 
in several canons. In one provision clerics recalled the decree of Nicephorus the Confessor, who had prescribed that when widows and widowers married, they were not to enjoy the same liturgy with which churchmen celebrated the marriage of virgins. Further, those who married a second time were to be refused the eucharist for two years, and those who took third spouses were to be denied the eucharist for five years. ${ }^{27}$ Another canon included the same prohibitions but allowed that if men or women were still young when they took second spouses, they might be prevented from taking the eucharist only one year; a third wedding, however, drew a five-year penalty, not only from the eucharist but from all services. In effect, they were excommunicated. Churchmen went on to forbid absolutely a fourth marriage. Quoting Gregory the Great as Fotii had before them, the Muscovite ecclesiastics saw a second marriage as a concession, the third as a violation of the law, "while a fourth is dishonorable, for this is a swine's life." 28

Similar provisions appeared in numerous other works of Orthodox penitential discipline. A late fifteenth-century collection, for example, had provided that a man who took a second wife was subject to fasting and deprived of the eucharist for a full year, the whole time executing 108 prostrations daily. A man who took a third wife was subject to "three or four years of fasting." ${ }^{29}$ A sixteenth-century canon titled Ashche dvoezhenets offered another, slightly different prescription. If a man repented having taken a second wife, he was subject to two years of penance, during which time every Monday, Wednesday, and Friday he was to fast and execute eight prostrations morning, noon, and night; he might receive the eucharist only once, at Easter. But if a man took a third wife, the canon went on, he could not receive the eucharist within the church, because "A third marriage is fornication and is called a beast's life [skotskim zhit'em narekaetsia], and [these people] are denied the eucharist for seven years, and they may not enter the church [during that time], and the guilty one must fast." ${ }^{30}$ A sixteenth-century Smolensk manuscript combines restrictions upon the sacrament with an outright prohibition of a third marriage:

Those who enter a second marriage are not to stand before the altar when they come to church to have their marriage blessed. Neither place crowns on their heads. Having entered the church, they should stand behind the ambo, and the priest there will pronounce the prayer over them and bless them.... The sacred council and holy apostles and church fathers decreed that there can be no third marriage. If some hierarch, knowing [their circumstance, nevertheless] blesses them [with the mar-

27. Stoglav, intro. W. F. Ryan (Letchworth, 1971), 85; E. B. Emchenko, Stoglav: Issledovanie i tekst (Moscow, 2000), 283.

28. Stoglav, 87; Emchenko, Stoglav, 284.

29. Pushkareva, ed., "A se grekhi zlye smertnye -," 51; Smirnov, Materialy, 61.

30. Pushkareva, ed., "A se grekhi zlye smertnye-," 53; Smirnov, Materialy, 63. On the origins of this text, see R. G. Pikhoia, "Opyt izucheniia rannikh novgorodskikh pamiatnikov tserkovnogo prava (Pravilo 'Asche dvoezhenets' i Voproshanie Kirikovo)," Vspomogatel'nye istoricheskie distsipliny. Sbornik 1 (Sverdlovsk, 1974), 9-16. 
riage sacrament], then expel him from the priesthood. If someone takes a third wife, then he may not receive the eucharist nor carry a candle into church. ... A third marriage is fornication and a beast's life. Those [who take a third wife] are prohibited from the eucharist and entry into church for seven years. ${ }^{31}$

All these texts make clear that Orthodox churchmen looked with disapproval on remarriage, even if some circumstances made it possible.

Whether those who remarried fulfilled all these demands is not clear, but church service books laid out separate wedding rituals for those entering a second or third marriage. For example, sixteenth-century handbooks instructed priests to alter the liturgy for those who were remarrying, so as to distinguish them from rituals celebrating first marriages. Among other things, the officiant was not to use the word marriage (brak) in praying over the couple, as he would for those celebrating the sacrament of a first marriage. Instead, he was to pray for those entering a second or third "coupling" (sovokuplenie), "because the wedding is on account of bodily needs." ${ }^{2}$ Although fifteenth-century manuscripts absolutely prohibited the use of crowns in the ceremony (thereby distinguishing a first wedding from its replication later), some sixteenth-century texts allowed the crowns but stipulated that they were to be placed on the shoulder instead of over the heads of the bride and groom. ${ }^{33}$

Visitors to Muscovy confirmed Orthodox reservations about remarriage and often mentioned them in accounts of their travels. Sigismund von Herberstein reported to his readers that, in sixteenth-century Muscovy, "if any one marry a second wife and become a bigamist [sic], they allow it indeed but scarcely think it a lawful marriage. They do not permit a third marriage, except for some weighty cause; but a fourth they allow to nobody and do not even consider it Christian." ${ }^{34}$ By calling remarriage bigamy, Herberstein emphasized the exact reason that Orthodox clerics found remarriage regrettable. The account from the 1661 expedition of Baron Augustin Freiherr von Mayerberg notes that in Muscovy "no one could take to himself a fourth wife after having been widowed three times." Mayerberg knew that Ivan IV had violated this regulation and had had as many as seven wives. But for ordinary Muscovites, he reported, whoever married a second time was refused entry to the church for two years, and if someone married a third time, he was deprived of the liturgy for twenty years. ${ }^{35}$ Jan Struys came to Muscovy just a few years later, and in his account confirmed the fundamentals of Mayerberg's report. Struys

31. Rossiiskaia gosudarstvennaia biblioteka, otdel rukopisei, f. 173.III (Moskovskaia dukhovnaia akademiia), no. 108, fols. 27-27v.

32. Aleksei Dmitrievskii, Bogosluzhenie v russkoi tserkvi v XVI veke (Kazan', 1884), 404.

33. N. Odintsov, Poriadok obshchestvennogo $i$ chastnogo bogosluzheniia $v$ drevnei Rossii do XVI veka (St. Petersburg, 1881), 283-84; Dmitrievskii, Bogosluzhenie, 405.

34. R. H. Major, ed., Notes upon Russia, 2 vols. (New York, n.d.), 1:93.

35. Puteshestvie v Moskoviiu Barona Avgustina Maierberga, in Chteniia v Imperatorskom obshchestve istorii $i$ dreunostei rossiiskikh pri moskouskom universitete, 1873, no. 3:83. Mayerberg went on to report, however, that divorce was common among the nobility, for whom barrenness proved sufficient reason to dissolve marriages and remarry, he claimed. Ibid. 
claimed that those who remarried were prohibited entry to the church forever, though they might attend from the porch or gallery; a third marriage resulted in total exclusion. ${ }^{36}$

Consequently, it seems clear that Muscovite canonists took seriously the sacramental content of marriage. In their view, not only did bigamy contradict the divine meaning of marriage, but so did any remarriage, which clerics accordingly tried to discourage. In devising separate rituals and in prescribing penances for serial monogamy, canonists tried to distinguish marriage and its spiritual content from the merely physical "coupling" that churchmen saw in remarriage. But how realistic were such views in early modern Russia? No study of remarriage in all Muscovite Russia yet exists, so we do not know how effectively clerics throughout early modern Russia distributed their views on marriage. Records from the Vologda archepiscopal court, however, demonstrate that across this vast expanse of northern Muscovy seventeenth-century churchmen applied generous time and resources to control bigamy and serial matrimony and met with more than modest success in inculcating in parishioners Orthodox understandings of the sacrament of marriage.

As Martine Segalen has observed, "in population patterns of past times, conjugal cells were broken up by mortality more frequently than nowadays, and remarriage was common." ${ }^{37}$ Although comprehensive records on both mortality and remarriage in early modern Russia are wanting, it is clear all the same that remarriage for widows and widowers was hardly unusual. For example, a seventeenth-century genealogical register compiled for Aristarkh Andreevich Iakovlev and his sons reports that Iakovlev first married Anna Ivanova doch' Kologreeva, with whom he produced several children. After she (and all her children) died, Iakovlev remarried, this time wedding a townswoman, Aksin'ia Vasil'eva doch' Aladvina. But soon she, too, died (as did two of her three offspring), so Iakovlev married again, taking as his third wife a widow from Serpukhov, Nastas'ia Ivanova doch' Nesterova. Consequently, by the time Iakovlev himself died in 1634 at the siege of Smolensk, he had married three times. $^{38}$ The well-known Muscovite boyar, A. S. Matveev, managed to marry four times, despite considerable difficulties caused by church authorities. ${ }^{39}$ Even fiction confirmed the practice of remarriage among the elite. The Tale of Savva Grudtsyn, for example, describes Savva's father,

36. John [Jan] Struys, The Perillous and Most Unhappy Voyages ofJohn Struys through Italy, Greece, Lifeland, Moscovia, Tartary. . . , trans. John Morrison (London, 1683), 146.

37. Martine Segalen, Historical Anthropology of the Family, trans. J. C. Whitehouse and Sarah Matthews (Cambridge, Eng., 1986), 32.

38. N. N. Kashkin, "Iz arkhiva Kashkinykh," Izvestiia Kaluzhskoi uchenoi arkhivnoi komissii, 1903, 15-16.

39. See, among others, S. G. Helmfelt to Bengt Horn, Narva, 15 September 1671 (enclosure Moscow, 29 August); 17 May 1672 (enclosure Novgorod, 6 May); and 24 May 1672 (enclosure Moscow, 7 May), Bengt Horns Samlung, vol. 11, Riksarkivet, Stockholm. See also Muscovitica, vol. 89, p. 99 (8 January 1674), Riksarkivet, Stockholm. My thanks to Martha Lahana for sharing this material with me. 
Bazhen, as being old but married to a young wife; she had never before been married, but for Bazhen the bride represented his third wife. ${ }^{40}$

Multiple marriages were not the exclusive preserve of the Muscovite dvorianstvo and merchantry; peasants, too, not infrequently remarried..$^{41}$ A 1695 case from the Vologda archbishop's archive describes the matrimonial history of Pron'ka Aristov, who had recently taken his third wife, the maiden Mavra Tarasova. Investigators discovered that Aristov had lived for seven years with his first wife before she died; after about a year and a half, Pron'ka took a new bride, the widow Matrenka Ivanova doch', and lived with her a year and a half before marrying his third wife..$^{42}$ The peasant Senka Isakov had a similar experience. As he wrote in his petition to the Vologda archbishop, "because of my sins I have been married to three wives, all of whom died." Still only twenty-eight years of age at the time of his petition, Isakov had spent a total of eleven years married to three women, but circumstances demanded that he find yet another wife, and so he requested the archbishop's permission..$^{43}$ Late in the seventeenth century, Pantelei Savel'ev, a peasant from the Komel'sk district, petitioned the Vologda archbishop on behalf of his widower son, Firs, requesting permission for him to take a maiden as his third wife. According to the petition, Firs was still only 20 , and he had lived with his first two wives a total of two years. For such a young man to remain unmarried was, the petitioner opined, not possible. ${ }^{44}$ Churchmen generally agreed with petitioners and authorized the issuance of marriage certificates, thereby allowing second and third marriages.

These approvals notwithstanding, church court records demonstrate that Muscovite laymen and laywomen understood clerical antipathy to remarriage, sometimes concealing earlier unions to qualify for a second or third wedding. For example, in 1695 Mironka Pavlov testified that at some past time he had abandoned his home on account of poverty and a shortage of available arable land: "my brothers multiplied so that there was no land to plow," he reported. He had already been married previously when he came to a village in Sudskii canton, where a widow married him, bring-

40. "Povest' o Savve Grudtsyne," in Pamiatniki literatury Drevnei Rusi. XVI vek. Kniga pervaia (Moscow, 1988), 40; Serge Zenkovsky, Medieval Russia's Epics, Chronicles and Tales, rev. ed. (New York, 1974), 455.

41. D. Gaunt and O. Lögren, "Remarriage in the Nordic Countries: The Cultural and Socio-Economic Background," in J. Dupâquier and E. Hélin et al., eds., Marriage and Remarriage in Populations of the Past (London, 1981), 55: "It is striking that remarriage was less frequent among the nobility and the clergy than among the peasants."

42. Arkhiv Sanktpeterburgskogo instituta rossiiskoi istorii (hereafter Arkhiv SpbIRI), koll. 117 (Collection of P. I. Savvaitov, Documents of the Vologda Archbishopric), op. 1, no. 1992.

43. Suvorov, Opisanie, 12:234. Similarly, Iakimka Ivanov reported that his wife, having grown ill, took the veil. Ivanov, now thirty, noted that he had been married twice already and petitioned for permission to take a third wife. Church authorities approved his request, so long as there was no other obstacle to his remarrying. Ibid., 5:79.

44. Arkhiv SpbIRI, koll. 117, op. 1, no. 1910. There is reason to doubt whether seventeenth-century petitioners were well informed about their exact ages. See Daniel H. Kaiser and Peyton Engel, "Time- and Age-Awareness in Early Modern Russia," Comparative Studies in Society and History 35 (1993): 824-39. 
ing him into her household. When the priest inquired of him whether there were any obstacles to his marriage and how many times he had been married before, Mirenko testified that "I, poor orphan, said that [it was my] third marriage," so that the priest married him. In March 1695, he continued, he fell ill and confessed to the priest that this had actually been his fourth marriage, not his third. "And now my spiritual confessor has prohibited me from entering church and prohibited me confession." 45

A 1648 case records the testimony of a woman who belatedly admitted that in remarrying she had concealed the fact that her first husband had died, so that her most recent marriage was her third, not her second as she had let the priest believe. ${ }^{46}$ Less duplicitous was Akilina Iakimova doch', who in a 1692 petition sought permission to take her third husband. Though still young (only 25), Akilina reported that her first two husbands had both died, and she had now found a new prospective groom. "To live unmarried is not possible," she wrote, "because of my youth." ${ }^{47}$ Churchmen approved her request, demonstrating that, whatever the church's disdain for serial monogamy, widowed men and women of early modern Russia did sometimes remarry. Demography and personal choice continued to drive practice.

The situation was more complicated for spouses whose partners had long abandoned them, but for whom confirmation of death was wanting. As with the widowed, abandoned spouses turned to the church to request permission to remarry. Church courts proved not unsympathetic to these petitions, but approval was not automatic. Invariably, churchmen mounted thorough investigations that aimed either to confirm the death of the fugitive or else to return him or her to the petitioner. In this way, church officials proved resistant to bigamous unions, whether accidental or intentional. Only when petitioners could demonstrate a prolonged absence without any news from the fugitive were church courts willing to presume the runaway dead. ${ }^{48}$

To justify requests for remarriage, and possibly to urge haste upon church investigators, abandoned peasant spouses frequently made reference to their material circumstances. As David Gaunt and Orvar Löfgren pointed out in describing remarriage in early modern Nordic communities, peasant households relied upon the labor of both husband and wife. Consequently, whether in first marriage or remarriage, mate selection

45. Suvorov, Opisanie, 7:105-7. Jennifer Lee Anderson cites a 1687 case that came before the Krutitsk archbishop, according to which a priest was denied permission to marry a man who contemplated his fourth marriage. See Anderson, "Gender Role Construction, Morality and Social Norms in Early Modern Russia" (Ph.D. diss., Ohio State University, 2001), 123. Yet Nina Minenko points out that in western Siberia peasants managed to marry four times at least occasionally, although with what consequences she does not say. Minenko, Russkaia krest'ianskaia sem'ia, 216-17.

46. Suvorov, Opisanie, 9:2-3.

47. Ibid., 9:129.

48. German authorities confronted similar cases, often meting out harsh punishments for wives who did not remain chaste during the absence of runaway husbands. Ulinka Rublack, The Crimes of Women in Early Modern Germany (Oxford, 1999), 214-15. 
depended in no small part upon the ability of a spouse to contribute to the household economy. A Swedish saying colorfully advised those in search of brides, "Do not look at girls at the church door, but rather by the dung heap." 49

Russian peasant households functioned according to a similar principle, and churchmen had to confront this reality in determining whether abandoned spouses might remarry, even if their missing partners had not been confirmed dead. A case from sometime after 1697, for instance, introduces Zakhar Iakimov, a peasant from Vologda province. When brought to the attention of church authorities, Iakimov reported that he had lived and labored alone for ten years; his wife, he said, had deserted him, and despite having instigated a formal search with the archbishop's help, "all this time I have heard nothing about her." In other words, Iakimov had respected canonical precedent and had sought the church's help in finding his wife so that they could be reunited. Now, however, he wanted to marry again: "I, your orphan, am young, and to live without a wife is impossible." Iakimov begged that the parish priest be authorized to issue a wedding memorandum. ${ }^{50}$

Similarly, sometime after 1664 the peasant Savka Kirilov petitioned the archbishop for permission to remarry. His wife had fled on 18 August 1664 , he wrote, leaving behind no trace, so that Kirilov professed not to know whether she were dead or alive. He could no longer tolerate living alone: "To live without a wife is impossible," he wrote; "there is no one to light the stove and cook" (pechit' $i$ varit' nikomu).$^{51}$ Senka Isakov, who had outlived three wives and sought permission to marry a fourth, reported a similarly depressing home life: "Disorder prevails in my home, for there is no one to light the stove and cook, no one to sew or wash clothes, no one to feed anyone." "For the sake of my tears and my loneliness and for the sake of my household order," Isakov's petition begged, please grant relief. ${ }^{52}$ The peasant Grigorii Sofronov, whose wife had also disappeared, sought permission to remarry, because otherwise "there was no one for him, poor orphan, with whom to live." ${ }^{33}$ Another peasant from the Russian north, Eleska Fedorov, complained about his fugitive wife who had deserted not only her husband but two young children as well. "There is no one to feed them, to give them drink, to sew for them, or to wash them," Fedorov reported. Embellishing a bit, he went on to foresee total disaster; things grew spare in every corner, he reported, and without relief he anticipated abandoning his household or falling into sin. Perhaps because of this rhetoric, Fedorov won his point. ${ }^{54}$

Isachko Eremiev attempted a similar justification for remarriage. Writing in 1687, Eremiev reported that his wife Ustin'ia had deserted him some fourteen years earlier, not because he had abused her, he was careful to point out, but by her own choice (samovolstvom svoim), "not wishing

49. Gaunt and Löfgren, "Remarriage in the Nordic Countries," 51.

50. Arkhiv SpbIRI, koll. 117, op. 1, no. 2086.

51. Suvorov, Opisanie, $11: 104$.

52. Ibid., 12:234.

53. Ibid.,1:41. See also a listing of similar cases from the 1630s: ibid., 2:4.

54. Arkhiv SpbIRI, koll. 117, op. 1, no. 2115. 
to live with me according to the law." Now all these years later Eremiev had no news of the woman, and his home was in ruins. He begged the archbishop to allow him to remarry "so that poor I will not finally be ruined and will not have to abandon my home." An inquiry confirmed the petitioner's report, as even the woman's father had to admit. ${ }^{55}$

Obrashko Silin's case was more complicated. His 1673 petition relates that his marriage to Mar'itsa Ivanova doch' had been a failure from the start. By his account his wife had not spent a single day with him in marriage, "the way wives [are supposed to] live with their husbands." Throwing over everything, Mar'itsa had run away immediately after the wedding, whereupon Silin had sought her out, found her, and returned her to their home. But hardly had Silin installed the woman back in their home than she had run away again, "no one knows where." In 1673, Silin had had no word of her for seven years, it had been thirteen years since they had married, "and not a single day has she lived with me" in all that time, Silin wrote. "I am disgraced and my home is deserted." Seeking to avoid abandoning his allotment and his tax duties, Silin asked permission to remarry. The court's investigation confirmed his claim, and in short order the archbishop approved his request. ${ }^{56}$

In 1677 the cotter Ivashko Bogdanov also petitioned for permission to remarry. Seven years ago, Bogdanov wrote, his wife Uliana, "by the will of God," had lost her mind and run away, leaving no trail (soshla bezvestno nevedomo kudy). Like others in his situation, Bogdanov sought the church's help. The archbishop's questioning of neighbors confirmed that Bogdanov had not driven the woman away and that she had fled of her own accord. But the petitioner's main concern was permission to remarry. "I live in my house alone, and for me, your orphan, to live unmarried is impossible," he wrote. Still young, Bogdanov asserted that he had too much work for one person, and he needed a wife. ${ }^{57}$

Whether churchmen granted his request we do not know, since the case preserves no record of a decision. But other cases include a fuller account of the investigations conducted by court officials and indicate how much the church courts valued first marriages. In a 1704 case Ivan $\mathrm{Zi}$ nov'ev reported that his wife, too, had fled seven years previously "without any trace." "For me to live as a peasant without a wife is impossible," Ivan protested and sought permission to remarry. The Vologda and Beloozero archbishop ordered an investigation, which officials promptly carried out. Neighbors confirmed that Ivan had not beaten his wife, nor had he driven her out. She had fled, they asserted, of her own will, and there had been no news since, so that no one knew whether she was alive or dead. Upon hearing this report, the archbishop ordered that Ivan be allowed to remarry and authorized the issuance of a marriage certificate. ${ }^{58}$

55. Suvorov, Opisanie, 5:57.

56. Ibid., 10:64-66.

57. Arkhiv SpbIRI, koll. 117, op. 1, no. 1179.

58. P. I. Shchukin, Sbornik starinnykh bumag khraniashchiesia v muzee P. I. Shchukina, 10 vols. (Moscow, 1896-1902), 4:53-55. Eve Levin discusses this case as well; see her Sex and Society, 125. 
A 1674 case features the same thoroughness and result. In January the peasant Fetka Ermolin reported that his wife had deserted him in 1660 and that in the intervening years he had had no news of her. Now he wanted to remarry. The archbishop's court immediately ordered an investigation, and by 3 February - just four days after the order had been issued - the archbishop's representative was at work interviewing the petitioner's neighbors. Altogether he consulted with nine peasants (and their neighbors) in four different villages; they all confirmed the petitioner's story and cleared Ermolin of the suspicion of having driven his wife away. By 17 February the archbishop had decreed that Ermolin be allowed to remarry, so long as he paid the appropriate fees. Mokeiko Kirilov received similarly prompt assistance when he petitioned the archbishop that same year; before the month was out Kirilov too received permission to remarry, his story fully confirmed by neighbors..$^{59}$

In all these cases, church officials seem to have decided to grant requests to remarry on the analogy with death. As much as they might have prized first marriages, Orthodox hierarchs were willing to grant survivors the right to remarry, so long as they did not marry often. When missing spouses had been gone so long that presuming their deaths was reasonable, faithful partners might at last gain permission to remarry. When the missing spouse was discovered alive, however, churchmen encountered more complicated domestic configurations that seriously tested their commitment to a first, sacramental marriage.

In a 1687 petition to the Ustiug archbishop's court, Anofrei Ivanov complained that six years previously his daughter-in-law, Matrena, had fled to points unknown. Recently, however, Ivanov noted, "a rumor had come his way" that the missing woman was living in the Ustiug district. Would the court please conduct an investigation, the petitioner requested, to see if the rumor was founded? Church investigators got right on the case, and within a few days found the missing woman and remanded her to Ustiug for questioning. There Matrena told churchmen that she had fled because both her husband, Stenka, and her father-in-law had regularly beaten her; she ran away to Ustiug district where she moved in with a man who fathered a child with her. As soon as the man saw that she was pregnant, Matrena testified, he chased her out, sending her to another parish where she later delivered a baby boy. Now attending mass before a new priest, Matrena had the baby christened. Before long, she celebrated a church wedding with a new husband, who fathered still another baby, with which she was now pregnant. Matrena appealed to stay with her new husband, observing that she had never had intercourse with Stenka anyway; besides, she added, she did not love him. Now that her husband and father-in-law had retrieved her, she testified, the beatings had resumed, and there was no intercourse either. Nevertheless, she asserted that she would agree to live with Stenka as church law demanded,

59. Suvorov, Opisanie, 12:1, 10. Anderson reports on several similar cases drawn from the archive of the Ustiug Archbishopric; see her "Gender Role Construction," 121-22. 
if he would have intimate relations with her and if he would cease beating her. The record does not say whether Stenka undertook to fulfill these conditions, but the archbishop did restore his wife to him. ${ }^{60}$

There is much in Matrena's story with which to fault parish officials, but the narrative also reveals Matrena's considerable appreciation for the clerics' understanding of marriage. In justifying herself to the archbishop's court, she touched on several issues that mitigated her apparently polygamous behavior. First, she blamed her husband and father-inlaw for assault, evidently knowing that the archbishop's investigators regularly inquired of neighbors whether husbands had beaten their wives, thereby forcing them into flight. Second, she took refuge behind the assertion that she and Stenka had never physically consummated their marriage, as she had with the man with whom she had celebrated a second church wedding. Finally, however, she cleverly expressed a willingness to return to her original husband, providing that he ceased assaulting her. By so saying, Matrena recognized that all her previous defenses were not sufficient to overcome the sacramental power of her first wedding.

The extant record does not report the reasoning behind the clerics' decision, but it cannot have been easy. Evidently no children from Matrena's marriage to Stenka existed to contradict the woman's claim about sexual relations. At the same time, Matrena had quite obviously conceived two children with other men, so that in deciding to return her to Stenka the church court had to rupture the family that Matrena had constructed with her new husband. But so far as the record can confirm, Ustiug churchmen did not flinch. From the beginning they assiduously prosecuted the case, first searching for Matrena, and then, once she was found, uncovering the whole history of her intimate life since she had fled. In the end, the church court came down firmly on the side of the sacramental permanence of a first marriage, disregarding the other consequences, regrettable though they might have been. ${ }^{61}$

A less thoroughly articulated case hews to the same principle. According to the testimony, Varvara Anfilof'eva, a peasant woman, had been married in a church wedding to Kirilo Onfileev. Despite the fact that she had been married against her will, as she maintained, Varvara lived with her husband for several years. But in 1657 she fled and, evidently with the collusion of her father, married another man, knowing that in the eyes of the church she was still married to Kirilo. Accordingly, the Vologda Archbishop Markel returned Varvara to her first husband, confirming the sacramental priority of her first marriage. ${ }^{62}$

Men also fled, sometimes taking up with new partners. But, as cases that came before the archbishop's court prove, when fugitive husbands returned, they, too, might expect to be reunited with their original wives, even if the wives had remarried in the meantime. For example, in a 1653

60. RIB 12, no. 180 .

61. Ibid. As Anderson pointed out in discussing this case, the husband might have divorced his wife for her adultery; see her "Gender Role Construction," 100.

62. Arkhiv SpbIRI, koll. 117, op. 1, no. 507. 
petition to the Vologda archbishop's court, a man reported that a decade earlier he had given his daughter in marriage to a peasant who belonged to the Rostov metropolitan. Soon after the wedding the husband had disappeared, and the abandoned wife was left to beg. To escape this fate, the woman had remarried without her father's permission and evidently without the priest's knowledge of her circumstance. At length, the wandering husband returned home and immediately filed suit against his father-inlaw. The court solved the dispute by returning the woman to her first husband, just as canon law prescribed. ${ }^{63}$

A 1685 case is more ambiguous, although the implied resolution is similar. Ortiushka Obramov reported that in December 1674 he had left home in search of a miracle cure for an unspecified illness, seeking to pray at holy sites of miracle-working saints. According to Obramov, he regularly sent letters home, but four years after his departure his wife remarried. For her part, the wife denied getting any letters and said that she had waited seven years for her husband. Finally, fearing rape or adultery, she said, she had remarried. It was not she who had violated the marriage bond, she pointed out, but her husband who had deserted her. The record does not preserve the decision of the archbishop's court, but it does include two citations from the canons of St. Basil and the Sixth Ecumenical council that suggest that churchmen intended to chastise the wife and return her to her first husband. In the absence of confirmation of her husband's death, the canons claimed, a woman's remarriage could count as nothing less than fornication. ${ }^{64}$

From another case we learn about Iakunka Iakovlev, who ran away sometime before 1648, leaving behind his wife, Olenka. Several years later she remarried, telling her new husband, Karpunka Fedot'ev, that she was widowed, a claim that the woman's matchmaker repeated. Now, however, Iakunka had reappeared and had filed suit against Fedot'ev. Pointing out that Iakovlev had been missing for nine years, and that he himself had been married to Olenka now for almost three years, Fedot'ev complained that he had paid two rubles for the wedding fee (vyvodnaia kunitsa) and another 1.2 rubles to the priest for the wedding. Iakovlev's petition, he complained, would ruin him and cause him great loss. The case record does not report the court's decision, but almost certainly Iakovlev got his wife back, just as other husbands and wives had when fugitive spouses returned. Even though it was Iakovlev himself who had run away and had therefore deserted his spouse, even though nine years had elapsed without word of the missing man, and even though his wife had been married to someone else for three years already, churchmen were bound to see the first wedding as having claims over Olenka's remarriage, especially since she had falsely claimed to have been widowed. Indeed, her decep-

63. Ibid., no. 292. New spouses did not always prove amenable to these decisions, however, as a 1704 case proves. See Suvorov, Opisanie, 7:139-40.

64. Suvorov, Opisanie, 10:102-9. V. Iu. Leshchenko refers to the canons of Basil the Great in claiming that in the early eighteenth century Russian churchmen regularly returned to first marriages those who had illegally remarried. Leshchenko, Sem'ia $i$ russkoe pravoslavie: XI-XIX vv. (St. Petersburg, 1999), 161-63. 
tion demonstrates quite powerfully that she knew the church's stance: without being able to claim her husband dead she had no chance of being married by a priest. ${ }^{65}$

Despite clerical insistence on the permanence of first marriages, canon law did provide some grounds for marital dissolution. As noted above, adultery could lead to divorce, but the records of the Vologda archbishop's court provide few cases based upon sexual misconduct. In a 1686 case, a man charged his wife, Solomanida, with having abandoned him after ten years of marriage. By his account, Solomanida had run away to live adulterously with Ivashko Chiura, with whom she had conceived a child. On hearing this news, the archbishop ordered her whipped "mercilessly." But Solomanida blamed her husband, who had, she said, been living adulterously in their own village with the maiden Kilikeika Gavrilova doch'. Unable to endure the shame, Solomanida said, she had run away, whereupon her husband had married Kilikeika and had produced two children with her. ${ }^{66}$

Whether churchmen permitted the divorce we cannot be sure, since the surviving record omits the decision. In an earlier case, however, church officials allowed divorce on the basis of sexual dysfunction. According to the 1653 petition of the widow Anniutka Osipova doch', her son-in-law Kozma Kornilov syn had failed to have a "legal bed" (zakonnaia lozha) with his wife, who testified that not once in six years of marriage had she had intercourse with Kornilov. She was so shamed by this circumstance, she reported, that she could not even tell her confessor.

Her husband disputed the claim, asserting that in the first years of marriage he and his wife in fact had had sexual relations, but there had followed a one-and-a-half year interval during which there had been none. More recently, he maintained, he and his wife had had sex "three or four times." The charges were serious, and the court treated them that way, dispatching a priest and deacon to examine Kornilov's genitalia. Their report does not describe what they found but does quote Justinianic law: "If a husband cannot be with his wife [i.e., has no sexual congress with his wife] for three years, the marriage is ended." The archbishop's court followed this precedent and granted a divorce. ${ }^{67}$

Although most of the records that survive describe remarriages that were in one way or another contested, not all cases fit this pattern. Occasionally a man or woman sought to abandon marriage and enter a convent or monastery, freeing the remaining spouse to seek a new partner. Orthodox canon law allowed this cause of marital dissolution, so long as the decision to take the habit was not the result of force or threat. Cases from the Vologda archbishop's archive reflect churchmen's keen interest in the motives of the prospective monks and nuns. Once satisfied that the choice of religious vocation was made freely, clerics permitted the dis-

65. Shchukin, Sbornik, 4:79.

66. Suvorov, Opisanie, 10:112-13.

67. Ibid., 10:29-30. 
solution of these marriages and granted the chance to remarry to the spouses they had abandoned.

For instance, church records preserve an emancipation memorandum from August 1695 in which the peasant woman Annitsa Ivanova doch' "voluntarily and not as a result of assault or torture, freely" renounced her marriage to Ivan Timofeev and allowed him "to marry another wife or live without a wife or be tonsured or live as he wishes." Annitsa reported that she could no longer fulfill her husband's expectations: evidently because of injury she could not do the work expected of a peasant nor could she take care of the household. ${ }^{68} \mathrm{~A}$ case from early in the eighteenth century proves less prolix but demonstrates the same point in reverse. According to the petitioner, his brother had been ill for more than thirteen years and had therefore freed his young wife, Natal'ia, so that she could seek another husband. ${ }^{69}$ In 1692 the peasant Stenka Mart'ianov petitioned for permission to remarry; his bride-to-be was described as a widow, hence the marriage would be her second as well. In fact, however, as Mart'ianov went on to relate, his bride's former husband was very much alive but had been tonsured in the Spaso-Prilutsk monastery on account of illness. The archbishop's officials found nothing to dispute and ordered a marriage certificate drawn up. ${ }^{70}$

A similar result attended a March 1653 complaint against Anisim Ostrovskii, who was accused of bigamy. The complainant pointed out that Ostrovskii had remarried, but his first wife, with whom Ostrovskii had lived a "long time" and with whom he had fathered three children, was still alive. When Ostrovskii appeared for interrogation a few days later at the archbishop's court, he did not deny that he had been married, but reported that his wife had fled their home nine years previously. He had remarried without waiting for her return, taking his new bride in a church wedding celebrated by the parish priest. But his first wife had learned about the remarriage, as the document then entered into evidence demonstrated. In the agreement that she presented to Ostrovskii, Mar'ia Fedorova doch' freely admitted that as early as 1637 she had fled her husband and their home, leaving no trace: "I ran away of my own will because I suffered from various illnesses and . . because I . . could not maintain my home." "It was I," she wrote, "who did not wish to live with him because I was ill." Accordingly, she set this record to paper and in it freed her hus-

68. Ibid., 7:123. Nada Boškovska and Boris Morozov, in introducing a 1687 divorce memorandum from Nikifor Larionov syn Islen'ev, report that only three such emancipation memoranda survive from the seventeenth century, but the cases cited here are far from rare; see "Razvodnaia zapis' XVII veka," Rodina, 1992, no. 10:95. Leshchenko describes a 1716 case, according to which the peasant Ivan Afanas'ev returned home from military duty to discover that his wife had married another man six years before. The two men agreed to a cash settlement (two rubles and four buckets of wine), in return for which Afanas'ev abandoned all claims to the woman and promised not to petition the authorities for her return; see Leshchenko, Sem'ia, 161-62. According to Minenko, in the early eighteenth century in western Siberia, peasants sometimes accepted significant sums from other men to issue such releases so that their wives could remarry; see Minenko, Russkaia krest'ianskaia sem'ia, 215-16.

69. Arkhiv SpbIRI, koll. 117, op. 1, no. 2227 (on reverse of the folios).

70. Ibid., no. 1911. 
band of all claims that she or her kin might make against him. ${ }^{71}$ Likewise Nenilka Varlamova petitioned the archbishop to allow her husband to remarry. She had taken the veil on account of illness, she wrote; she had had both arms and legs amputated and could therefore no longer live with her peasant husband. ${ }^{72}$ Another woman exercised her own initiative in abandoning her husband for the convent. According to the surviving testimony, no one knew of her resolve until she appeared in Beloozero in a habit and announced her move. As her husband hastened to point out, the woman had voluntarily made this decision, not because she had been beaten. On the basis of the evidence, the archbishop allowed the husband to remarry. ${ }^{73}$

Even in the face of agreement, sometimes plans for entering a monastery went awry, as a 1667 case demonstrates. The petition came from a Vologda mason named Iakunka Fokich, who had married the daughter of a mead brewer. At some point after his marriage, Iakunka fell seriously ill, punishment from God for his sins, he thought. By his own account he was "out of his mind" (vne uma) for two and a half years, so that his wife had remarried. Now, however, he had regained his mental health. When questioned, Fokich's wife Ustin'ia said that her husband had suffered from epilepsy (paduchaia bolezn') and other ills, and that he had petitioned to be tonsured as a result. ${ }^{74}$ Fokich admitted that he had been very ill; things had reached such a point that he did not even know people, and therefore he had promised to be tonsured in the Prilutsk monastery. A 1665 decree of Archbishop Simon provided for his tonsure, and Fokich left behind a petition requesting a divorce. But, he continued, as "a poor, senile, handicapped, helpless orphan, naked and barefoot," he had had no money to pay for his tonsuring. Furthermore, for a long time he was seriously disabled, overcome by mental illness and largely confined to bed. He had not, therefore, been able to complete his promise before the miracle-working Antonii had unexpectedly cured him of his illness. Joyous at his rescue and forgetful of his promise, Fokich returned to Vologda only to find his wife, who had thought him long since tonsured, married to someone else. She no longer wished to live with him, nor was she any longer necessary or desirable for Fokich. Consequently, he petitioned the archbishop's court to note that he was no longer Ustin'ia's husband and that she was no longer his wife, and to provide a decree to that effect. ${ }^{75}$

On other occasions, regret seems to have led the principals to rescind agreement to take a religious vocation. For example, in 1662 the towns-

71. Ibid., no. 281.

72. Suvorov, Opisanie, $1: 39$.

73. Ibid., $1: 32$.

74. On the frequency of epilepsy and other ailments in early modern Russia, see Daniel H. Kaiser, "The Poor and Disabled in Early Eighteenth-Century Russian Towns," Journal of Social History 32 (1998-99): 131-34.

75. Suvorov, Opisanie, 11:126-29. Mental illness informed other suits, as well. In one case a Vologda townsman claimed that his wife had fled from him on account of mental deficiencies (po maloumiiu), and in another a slaveowner reported that the wife of a household servant had fled because she was out of her mind (zne uma); he wanted to have the servant remarry. Ibid., 2:45, 11:134. 
woman Kaptelina Logteva petitioned churchmen, alleging that her husband had unjustifiably forced her to take the veil the preceding year so that he could marry another woman. But the convent's elder disputed her claim, introducing as evidence a petition from Kaptelina herself in which she sought permission to enter the convent. "Because of my sins," the document read, "I have fallen ill, and I can no longer live with my husband, and because of my illness I can no longer do peasant's work ... Please free me from my husband and bless my taking the veil." In a familiar formula, the petition concludes with the signature of Kaptelina's confessor, who confirmed having signed the document in place of Kaptelina and "according to her order."76

A 1654 case comes from the hand of Fedositsa Prokhorova, whose petition alleged that her husband had abandoned her eight years earlier and that she was therefore left "hungry and cold." Now, however, she said that rumor had reached her that her husband was alive and had married again. She, meanwhile, was neither widow nor married woman; there was no one to feed her and provide her drink. Interrogation of her husband produced a different story. Yes, Gurei admitted, he had been married to Fedositsa and had lived with her for four years, during which time they had produced a son who had unfortunately died soon after christening. Gurei ran away, he said with no evident shame, because his wife fell seriously ill and lay near death's door. In flight Gurei had remarried, and he identified the priest who had performed the ceremony. But in none of this was he guilty of bigamy, he claimed, because his first wife, Fedositsa, had issued a document in which she requested permission to take the veil. There she wrote that she and Gurei had in fact been too closely related to marry, and "by God's justice on account of my sins I have fallen ill with a 'dark sickness' [chernaia neduga]." By asking for permission to enter a convent, Fedositsa simultaneously freed Gurei, promising to make no claim against him for her dowry or for payment to support her monastic cell. On hearing this text read, Fedositsa withdrew her petition and was immediately given the veil. ${ }^{.7}$

But such an accommodating perspective was rare. Conflict seems to have surrounded many cases in which marital dissolution hinged on one of the partners entering a church house. For example, in 1650 the fatherin-law of Tret'iak Savel'ev syn Subotin petitioned church authorities on behalf of his daughter, who had married Subotin some time before. According to the petition, Subotin had submitted his wife to beatings such that he had broken her hands and legs, all in an effort to get the woman to take the veil, thus freeing him to remarry. Subotin denied these claims, reporting instead that his wife had fled, abandoning him. When he found

76. Ibid., 9:18-23. In a case from the 1650s, the wife of townsman Ivashka Filippov requested permission to take the veil, threatening to kill herself if her request were not granted. Ibid., 1:6.

77. Arkhiv SpbIRI, koll. 117, op. 1, no. 365. For a similar, much longer case involving a dispute about whether the woman had deserted husband and children for a monastic vocation, see Rossiiskii gosudarstvennyi arkhiv drevnikh aktov, f. 210 (Military Affairs Chancellery), d. 226, Prikaznyi stol., fols. 1-52 and d. 238, fols. 1-19, 60-61. 
her and brought her back home, he said, he asked her in the presence of her father and neighbors why she had run away and whether she had suffered any shortage of food or drink, whether he had beaten her. No, the woman had replied; she claimed to have had plenty to eat and drink and asserted that she had suffered nothing at her husband's hand. Rather, she had fled because of failing abilities and handicaps (svoei nemoshchi $i$ uvich'ia), and she wished to take the veil. Subotin claimed that he had agreed to this course, and that because his father-in-law denied being able to pay for her tonsure and upkeep, Subotin himself had agreed to pay the costs. But then, en route to Sukhona where the woman was to enter a convent, her father stole her away, along with all her things. Perhaps surprisingly, Subotin reported that life alone was difficult; like other petitioners he reported that his homestead was desolate and in need of a woman's care. He wanted to live with his wife, he said, and asked for a hearing ${ }^{78}$

It is not difficult to believe, though, that some husbands did try to force wives into convents, hoping thereby to create for themselves new unions. A 1689 case features exactly this charge, which, despite the husband's denial, seems quite credible. Fekolka, wife of a Vologda townsman, testified that that very day her husband had beaten her with the aim of obliging her to petition the archbishop for a divorce so that she could enter a convent. This claim is not rare in church court petitions, but the report on Fekolka's appearance inclines the reader to sympathize with her plight. According to a physical inspection of the woman, Fekolka exhibited obvious black-and-blue marks and a serious wound as well. Her ears were all bloody, the report maintained, and her right earlobe had been ripped off; she had a shiner, and both her right and left shoulders were blue with bruises; her head gave evidence of hair having been torn out by the roots. Fekolka testified that all this was the result of a beating her husband had administered. If she did not petition churchmen for a divorce, Fekolka continued, he promised worse: he threatened to kill her if she did not take the veil. The record does not include the disposition of the case, so we cannot be sure if the inquest disproved her husband's defensethat he had beaten her because she had stolen a silver cross and some other property. At a minimum, however, the narrative demonstrates how deeply imbedded in consciousness was the layman's understanding of the power that taking a church vocation might have on marriage. Without securing the archbishop's consent for Fekolka to enter a convent, her husband foresaw little chance of finding a new wife. ${ }^{79}$

The seventeenth-century cases heard before the archbishop's court introduce a wide array of claims about remarriage. Naturally, litigants made of the documents at their disposal the most appealing cases they could, hoping that their rhetoric would win them the hoped-for results. As contesting claims prove, the facts of the case were not infrequently at issue, and we must assume therefore that at least some litigants resorted to exaggeration and fabrication.

78. Suvorov, Opisanie, 11:31.

79. Ibid., 7:85-86. 
For their part, church officials did their best to penetrate the blizzard of charges that frequently accompanied litigation over marriage. As demonstrated most powerfully in cases where spouses were reported to be long-missing, church officials quickly and thoroughly investigated the charges, inquiring of neighbors and relatives whether the married couple had lived together amicably, whether the husband had beaten his wife, and when and why the missing spouse had fled. When evidence surfaced that the fugitive was alive somewhere else, church officials promptly followed the trail, and whenever possible retrieved the runaway for interrogation.

Even when fugitives could not be found, when they had disappeared without a trace into the far reaches of Muscovy, seventeenth-century church courts undertook a solemn review of the facts. Only if no proof had surfaced in many years and only if there were no evidence that the remaining spouse had driven the other into flight would the archbishop authorize a new marriage for the survivor. Churchmen had to sort through sometimes complicated charges; they also had to evaluate the rhetorical flourishes with which petitioners regularly adorned their requests. In the end clerics often allowed abandoned spouses to remarry. But church law had its limits, even for widows and widowers: fourth marriages were strictly forbidden and violators punished.

Archepiscopal courts occasionally permitted the dissolution of marriages, despite the commitment of Orthodox canon law to sacramental marriage and its permanence. To separate living spouses required serious justification, however, and churchmen only rarely found justifiable cause. When a man or woman voluntarily took the veil or habit, in this way symbolically leaving the secular world, church courts were inclined to authorize remarriage for the one left at home alone. But here, too, church officials were careful to examine the particulars of the case to make certain that no unreasonable force had compelled the departing spouse to take a religious vocation. Several cases confirm that even when women made such allegations against their husbands, officials carefully sifted through the evidence before deciding whether to approve petitions for remarriage.

The evidence marshaled here comes mainly from a single region of early modern Russia, and until study of other regions confirms the practices evident in the Russian north, the full extent to which early modern churchmen succeeded in controlling remarriage will remain unclear. Nevertheless, the surviving records demonstrate unequivocally that throughout the broad stretches of Russia's north seventeenth-century clergymen, no less vigorously than their successors a century later, labored conscientiously and effectively to uphold the sacramental value of Orthodox marriage. Even though some prominent Muscovites managed multiple marriages and even though the church turned a sympathetic ear toward peasant pleas for remarriage in the face of long-absent or deceased spouses, early modern Russian churchmen decisively and often embraced the sacramental importance of first marriages. Indeed, even when confronted with complicated domestic configurations that resulted 
from remarriages when neither divorce nor death separated the original spouses, seventeenth-century churchmen regularly affirmed the primacy of sacramental marriage by returning errant spouses to their original unions.

Evidence introduced here also contradicts the assertion that early modern Russians did not much heed Orthodox instruction or ritual. The very fact that petitioners regularly sought from churchmen permission to remarry underlines lay people's acknowledgment that marriage and its proper conduct were fully within the purview of the church. Furthermore, in the course of justifying their claims before church courts, early modern Russian Christians betrayed a keen sense of the fundamental principles of Orthodox teaching on marriage. By their own testimony, petitioners reported living difficult lives in the absence of spouses long not heard from; these peasants attempted to get along for six, seven, even ten or more years, and only at length did they direct to church courts rather desperate pleas for permission to remarry.

Even the most rebellious, disobedient Muscovite Christians revealed in their testimony that, in deserting their original spouses, even if they later remarried and produced new children, they had not escaped the bonds established by sacramental marriage. Short of approval from a church court, a man and woman who celebrated a church wedding were forever married-even if they lived apart for years, even if they subsequently found new partners, and even if they separately produced new children - and therefore at the end of time could expect to be rejoined as man and wife. 